\title{
INTEGRATED COMMUNICATIVE LEARNING APPROACH IN ELP PRACTICE: Practical application in the context of intra/multi/inter/transdisciplinary integration
}

\begin{abstract}
English for Legal Purposes (ELP) or Legal English (LE) is a prominent area of English for Specific Purposes (ESP), catering for the specific discourse community needs and purposes. This article presents the Integrated Communicative Learning (ICL) approach to instructional design within the curricular framework of ELP/LE courses for academic and professional purposes (LEAP/LEPP) in tertiary education. This holistic approach includes ample intradisciplinary, multidisciplinary, interdisciplinary and transdisciplinary dimensions. The first part of this article presents the conceptual, structural and theoretical framework of this approach, and its many pedagogical and methodological functions. The second part outlines the structural framework of the three ELP/LE courses, the teaching/learning context, and the rationale for selecting this approach. The third part focus the practical application of the ICL in these courses, with reference to examples of intra/multi/inter/transdisciplinary integration. Finally, the author discusses the benefits, challenges and considerations in implementing this approach, particularly in view of promoting authentic learning and inter/transdisciplinary legal education.
\end{abstract}

Keywords: ESP, ELP/Legal English, integrated communicative learning, authentic learning, global competence, transferable skills.

*goga@prafak.ni.ac.rs 


\section{Introduction}

Integrative Learning has been part of general, legal and language education since the early $20^{\text {th }}$ century ${ }^{1}$. English Language Teaching (ELT) pedagogy has engendered a range of integrative approaches. ${ }^{2}$ In the $21^{\text {st }}$ century, the corpus has been supplemented by Digital Learning varieties. ${ }^{3}$

English for Specific Purposes (ESP) pedagogy, methodology and practice integrate all these approaches in an effort to put them to good use. While some approaches have gained prominence in the $21^{\text {st }}$ century (PBL, CLL, CLIL, ComBL), ESP instruction is hardly ever confined to a single approach. Given the complex and dynamic nature of ESP, as well as distinctive target learner needs, practitioners prefer to keep the gates open for alternative learning solutions. Thus, they resort to integrating different approaches. As an interdisciplinary area aimed at bridging the gap between education and real-world applications, ESP integrates different intradisciplinary, multidisciplinary, interdisciplinary and transdisciplinary perspectives, taking into account the views of relevant stakeholders (institutions, subject-teachers, practitioners, employers, learners). The integration of diverse approaches and perspectives inevitably entails a quest for "situationally relevant pedagogy" (Larsen-Freeman, Anderson, 2011: xii). In ESP, it often results in the development of ESP-specific pedagogy and methodology.

The $21^{\text {st }}$ century global trends have prompted the expansion of English for Legal Purposes (ELP) or Legal English (LE), aimed at facilitating an effective law-andlanguage instruction for academic, professional and occupational/vocational purposes. The Integrative Learning provides a broad conceptual, theoretical, pedagogical, methodological, and structural framework that may most comprehensively depict the various dimensions of ELP/LE instruction.

This article provides an insight into the Integrated Communicative Learning (ICL) approach applied in ELP/LE instructional design for academic and professional purposes (LEAP/LEPP) at the Faculty of Law, University of Niš. The article first presents the ICL conceptual and structural framework, and its many theoretical, methodological, pedagogical, psychological, developmental, functional and

1 For more on the theoretical framework of Integrative Learning, see: Ignjatović, 2020:179198

2 The extensive list includes: Experiential Learning/EL, Task-based Learning/TBL, Community Learning/CL, Communicative Language Teaching/CLT, Multiple Intelligences Theory/MI; Project-based Learning/PBL, Content-based Learning/CBL; Cooperative Language Learning/CLL, Content \& Language Integrated Learning/CLIL, Competency-based Learning/ ComBL; for more, see: Larsen-Freeman \& Anderson, 2011:v.

3 E.g. Computer-Assisted Learning/CAL, Flipped Learning, Blended Learning, Distance Learning, Mobile Learning, E-Learning: Virtual Learning Environments (VLE), Learning Management Systems (LMS), and "Gamification". 
pragmatic functions. The second part outlines the structure of these courses, the teaching context,, and the rationale for selecting this approach. The third part focuses on the practical application of the ICL in three ELP/LE courses, including examples of intra/multi/inter/transdisciplinary integration. In the last part, the author discusses the challenges and benefits of implementing the ICL, particularly in view of promoting authentic learning for real-life discourse community purposes and inter/transdisciplinary legal education.

\section{The Integrated Communicative Learning Approach in ELT and ESP}

The concept of Integrated Communicative Learning (ICL) is a theoretical-methodological construct indicative of a holistic approach encompassing multiple approaches, dimensions and perspectives. This "label" does not depict distinctive features of many approaches which are intrinsically embedded in the ICL: Experiential Learning/EL, Multiple Intelligences/MI, Task-based Learning/ TBL, Project-based Learning/PBL, Communicative Language Teaching/CLT, Content-based Learning/CBL, Cooperative Language Learning/CLL, Content and Language Integrated Learning/CLIL, Competency-based Learning/ComBL, Digital Learning/DL; nor does it depict the multidimensional integration of other intra/multi/inter/transdisciplinary perspectives. ${ }^{4}$ Yet, its broad framework offers sufficient latitude for examining the underlying features and presenting its implementation in the specific ELP/LE tertiary education setting.

The structural framework of the ICL approach entails correlation and integration of at least three distinctive approaches: communicative language learning, integrative learning, and authentic learning, which are the cornerstones of ESP instruction. As each of these concepts entails a set of correlated approaches and contemporary concepts, they are briefly reviewed here.

\subsection{Communicative Language Teaching (CLT) in ELT and ESP}

The CLT is an integrated approach which emerged in the 1970s, in an effort to integrate the key elements of communication (purpose, context, content knowledge, competences, values) and address learner needs by focusing on diverse socio-linguistic issues (integrated language skills; language functions in social/intercultural contexts; discourse and rhetorical skills; contextualized practice on form/meaning/use, coherence/cohesion in production, accuracy/ fluency in performance) and pedagogical, methodological, psychological issues (cognitive, behavioral, developmental factors; topic/task-based, project-based,

4 For more on the intra/multi/inter/transdisciplinary integration approaches, see: Ignjatović, 2020:184-186. 
experiential learning ${ }^{5}$, multiple intelligences; ${ }^{6}$ authentic sources, hands-on activities: role-play, games, projects; learning skills, learner autonomy; varied assessment; etc.) (Richards, Rogers, 1986:67-68; Richards, 2006:14-21). Thus, it incorporates features of other interactive approaches (EL, MI, TBL, PBL, CBL, CLL) or their distinctive features (principles, methods, techniques, strategies, instruments, activities).

For all these tenets, the CLT has had a huge impact on subsequent ELT and ESP developments to date. First, the CLT pedagogy and methodology engendered the concept of communicative syllabus, which includes several syllabus types: structural, functional, notional, topic/theme-based, task/content-based, and integrated skills-based syllabus (Richards, 2006:10-11). Second, the CLT generated the concept of communicative competence, ${ }^{7}$ which includes a set of correlated competences: a) linguistic competence (vocabulary, grammar, structures, functions); b) socio-linguistic competences (socio-cultural, functional, pragmatic rules, spoken/written communication, formal/informal range/register); c) discursive competence (texts/genres, professional skills, interaction rules,); and d) strategic competence (learner/learning skills, interpersonal skills) (Richards, Rogers, 1986:70-71). Third, as this eclectic approach proved to be adaptable to various contexts, the communicative syllabus and communicative competence have become the bedrock of ESP. Accordingly, the CLT is the fundamental approach in ESP.

\subsection{Integrative Learning in ELT and ESP}

Integrative Learning is a holistic learner/learning-centered approach, aimed at correlating a range of intra/multi/inter/transdisciplinary perspectives, transferring knowledge and competences across contexts, cultivating inter/transdisciplinary mindsets, and generating an integrated system of knowledge, competences and values applicable in real-world contexts (Klein, 2008:406-407). Its pedagogical framework rests on multiple approaches (EL, TBL, MI, PBL, CBL, CLL, CLIL, ComBL, DL). The structural framework for integrative processes is the integrated curriculum.

5 Postulated by J. Dewey (1938) and developed by D. Kolb (1984), Experiential Learning Theory entails learning by doing and discovery, reflection, learning from experience, and application in new contexts (Leicester Uni., 2020).

6 For more on H. Gardner's Multiple Intelligences Theory (1983), see: Ignjatović, 2017a: 569-570.

7 For more on the communicative competence, and each integral competence, see: Ignjatović, 2017a: 581-582. 
The integrated curriculum entails various aspects of integration: a) integrative content, courses, programs, projects (multi/inter/transdisciplinary); b) integrative pedagogy, methodology (authentic, holistic, humanistic, experiential learning); c) integrated syllabus (learner/learning-centered, standards/outcomes-based, knowledge/competence/value-based) d) integrative goals, objectives (knowledge/competences/values, processes/practices); e) integrative processes (correlation, reconstruction, transformation); f) integrative activities (research-based, problem/project-based, competency/performance-based; process/ product-based); g) integrative competences (critical thinking, problem-solving, decision-making); h) integrative strategies (learning skills, learner autonomy, collaboration); i) integrative assessment (formal/informal, summative/formative); j) integrative experiences (collaborative projects, learning/professional communities); and k) integrative outcomes (communicative competence, global competence, transferable skills) (Klein, 1999:16-23; Newell, 2010:8-11). The elaborate structure of the integrated curriculum points to multiple ICL functions: theoretical, pedagogical, methodological, socio-linguistic, functional, strategic, psychological, developmental and affective.

\subsection{Authentic Learning in ELT and ESP}

In ELT, authentic learning is a holistic approach aimed at correlating institutional study with real-life (GSP, 2013) and ensuring meaningful, practical and effective learning in real-life contexts or for real-life purposes. In ESP, the concept of authenticity is all-inclusive.

Authentic learning is the pivotal and inherent feature of ESP instructional design. It may be defined as the acquisition of authentic competences required in authentic contexts, for authentic purposes of the specific discourse community. Authenticity is an integral part of all stages of ESP instruction: a) authentic approach (learner/learning-centered, ESP-specific pedagogy) to authentic design (content/competences/practices); b) authentic needs for authentic purposes in authentic contexts (expertise for professional performance in discourse events); c) authentic knowledge, competences, values (lawyer expertise, skills, integrity); d) authentic sources, materials, activities (texts, audio-visuals; problem-solving) (Breen, 1985); e) authentic interaction, communication, collaboration (speaker-audience, debates, projects); f) authentic culture, conduct (negotiation; legal reasoning); g) authentic goals, outcomes and assessment (persuasive legal argumentation; peer-assessment); h) authentic environments (legal clinics, conferences); i) authentic experiences (mock trials, moot courts) (Gilmore, 2007); (Pinner, 2012: 28-32). As these facets are inherently correlated and complementary, they facilitate holistic learning. The use of authentic contents often generates ESP-specific pedagogy and methodology. For example, legal 
case method differs in purpose, structure, content and requisite competences from case studies in other social sciences. Thus, it has to be explored from the discourse community perspective. Yet, besides the discursive competences, the ICL includes two generic competences.

\subsection{Global Competence and Transferable Skills}

Under the OECD Learning Framework 2030, the global competence entails four assets of quality learning: a) Knowledge (disciplinary, interdisciplinary, epistemic, procedural); b) Competences (cognitive, social, discursive, affective); c) Attitudes (conduct, beliefs, judgment); and d) Values (personal, professional, local, global) (OECD,2018:4-5). It implies four capacities: 1) to examine issues of local/ global relevance; 2) to understand, appreciate and evaluate different perspectives; 3 ) to establish positive interactions with people of different backgrounds; and 4) to take constructive action for sustainable development and well-being (OECD PISA, 2018:7-8).

Proposed at the outset of the $21^{\text {st }}$ century and developed within the UNESCO's Integrated Learning for Sustainable Development, ${ }^{8}$ the concept of transferable skills has recently been updated within the UNICEF's Global Framework on Transferable Skills (2019), which identifies five learning dimensions (cognitive, instrumental, individual, social, action capacities) ${ }^{9}$ and four essential skills needed for efficient learning, productive employment and constructive participation in society: a) foundation skills (literacy, communication, cooperation); b) digital skills (literacy, ethics, data management); c) transferable skills ("soft" skills: socio-cultural, emotional, generic life/career skills), and d) job-specific skills ("hard skills") (UNICEF, 2019:1). In particular, the concept of transferable skills comprises three categories of competences, each entailing a set of skills: 1) cognitive skills (critical/analytical thinking, problem-solving, decision-making, data management, life-long learning); 2) socio-cultural skills (interpersonal/intercultural communication, collaboration, conflict resolution); and 3) emotional skills (self-awareness, self-regulation, responsibility, integrity, empathy) (UNICEF: 2019:10). Each skill comprises a set of sub-skills and micro-skills; for example, life-long learning includes: a) critical thinking (active listening, cognition/metacognition, questioning, analysis, synthesis, interpretation, reflection); b) problem-solving

8 Within the UN Sustainable Development Agenda (2002), the UNESCO's 21 $1^{\text {st }}$ Century Learning Framework envisaged 3 essential skills: 1) Learning skill; 2) Literacy skills; and 3) Transferable life skills (UNESCO, 2012:11).

9 Based on the UNESCO's Education for Sustainable Development Initiative Report (2012), the UNICEF identified five learning dimensions: 1) cognitive dimension (knowledge); 2) instrumental dimension (competences); 3) individual dimension (values); 4) social dimension (interpersonal/intercultural cooperation); and 5) action dimension (active citizenship, constructive action, innovation) (UNICEF, 2019: 12). 
(analytical thinking, social responsibility, constructive solutions, negotiation, conflict resolutions); c) creativity (divergent thinking, innovation, effective articulation, performance) (UNICEF: 2019:19); and d) learning skills (learning strategies, learner autonomy; self-management, motivation, confidence) (UNESCO-IBE, 2013:25). The examples show that transferable skills are not viewed as a fixed set of competencies and attributes; they are fluid, changeable and adaptable to the specific learner needs and learning contexts.

The integration of all these approaches, perspectives and competences may be facilitated by devising an integrated competency-based and outcomes-based curriculum (OECD, 2018: 5).

\section{Integrated Communicative Learning Approach in ELP/LE instruction}

The presented conceptual, structural, pedagogical and methodological framework of the ICL approach has been the foundation of the integrated ELP/LE curriculum design at the Law Faculty in Niš. The part of the paper provides an overview of the structure of the ELP/LE courses, the learning context, and the rationale for selecting the ICL approach.

\subsection{A brief overview of ELP/LE courses at the Law Faculty, University of Niš}

The current LF curriculum comprises three ELP/LE courses: a compulsory first-year ELP course (3h/w, 45h; B1/B1+CEFR) ${ }^{10}$ and two elective LE courses $(3+1 \mathrm{~h} / \mathrm{w}, 60 \mathrm{~h}$ each): the third-year LE1 course (B1+/B2) and the fourth-year LE2 course (B2+/C1). The current distribution of courses across three semesters in three years was instituted in the last two accreditation cycles (2013-2018, 2018-2023), but the core framework was developed in the period 2002-2009. The course syllabi, materials and methods have been revised, updated and adapted ever since. The instructional design has evolved, in line with the ongoing intra/ multi/interdisciplinary research, professional development, cooperation with law-and-language experts, learner evaluation, etc.

\subsection{Target Learners and Learning Context in ELP/LE Courses}

The target learners in the first-year ELP course (B1/B1+) are undergraduate law students (aged 19-20), who attend classes as a single mixed-ability group (60-70 learners per year). The Present Situation Analysis (PSA), including the

10 The Common European Framework of Reference (CEFR) is an international standard for assessing language competences on a six-level scale (2001): beginner (A1), elementary (A2), pre-intermediate (B1), intermediate (B1+), upper-intermediate (B2), advanced (C1), and proficiency (C2); for more, see: CoE (2020). 
language needs analysis at intake, shows that most learners have been exposed to General English (GE); they have different proficiency levels (B1 to B2+/C1), different habits and attitudes to learning, and different perceptions of linguistic, academic and professional needs for real-world purposes. The Context Analysis (CA) shows that classes take place in a traditional classroom setting (fixed-desks, low-tech environment), including the use of technology in class (CAL) and elements of Blended Learning (online sources). The Target Situation Analysis (TSA) shows that law professionals need generic and specific competences for performance in different real-world contexts. As learners' professional needs remain indefinite (rather than specific), the ELP/LE course aims to raise awareness about LE applications, facilitate the acquisition of both generic and discursive competences, and promote authentic and holistic learning for academic and professional purposes.

The target learners in the $3^{\text {rd }}$ and $4^{\text {th }}$ elective LE courses are law students (aged 22-25+) who have already taken the first-year ELP course; they are intrinsically motivated to explore new LE horizons. These groups are smaller (10-15 students per year) and learners' proficiency levels are more homogenous (B1+/ B2 and B2+/C1, respectively). The LE courses focus on subject-specific content knowledge and discourse culture, facilitate the acquisition of related discursive and generic competences, and promote life-long learning for personal and professional purposes.

\subsection{The rationale for applying the Integrated Communicative Learning Approach}

At the outset of the $21^{\text {st }}$ century, there was a need to reconsider and reconstruct ELP instruction in line with the contemporary developments in ESP pedagogy. To this effect, the ELP/LE course design was rooted in the Integrated Communicative Learning (ICL) approach, which offers ample opportunities for integration and devising meaningful learning opportunities. Based on the Experiential learning theory, MI theory, learner/learning-centered pedagogy, and contentbased, tasks-based and competence-based methodology, this approach is aimed at fostering the communicative competence through inter/multi/intra/transdisciplinary integration, fostering learner/learning skills, learner autonomy and life-long learning (Ignjatović, 2009: iii), and promoting authentic learning for real-world purposes, transferable skills for employability and constructive social engagement, and the global competence for sustainable development.

Moreover, as integrative learning approach gained ground in legal education ${ }^{11}$, there was a growing focus on essential legal skills: a) cognitive competences (legal

11 For more on integrative learning in legal education, see: Ignjatović, 2020: 182-183 
literacy; doctrines, rules, procedures); b) professional competences (legal research, case analysis, critical thinking, argumentation, interpretation, evaluation, problem-solving, public speaking, advocacy skills); c) professional identity and responsibility (values, ethics, conduct, judgment); and d) personal qualities and interpersonal communication competences (time/data management, collaboration, conflict management; responsibility) (Munro, 1991:7; Wegner, 2011:14-19). Professionalism and employability at the global labour market were reinforced by fostering global legal skills (2005): a) professional competences; b) language competences (Legal English); and c) socio-linguistic, strategic, intercultural competences (GLS, 2010). The recognition of Legal English as a lingua franca at the global level has been an incentive for further development of ELP/LE instruction.

\section{Multidimensional alignments in ELP/LE integrated curriculum design}

Given that integrative learning calls for "the new quadrangulation of disciplinary depth, multidisciplinary breath, interdisciplinary integration and transdisciplinary competences" (Klein, 2008:406), this part focuses on the "quadrangulation" of these dimensions in ELP/LE practice, ${ }^{12}$ and illustrates the implementation of the ICL approach in ELP/LE courses offered at the LF Niš.

\subsection{Intradisciplinary integration}

This intradisciplinary integration is reflected in the core dimensions of lawand-language instruction: knowledge/competences/values and pedagogical/ methodological approaches.

In terms of language, intradisciplinary integration includes a body of distinctive features associated with linguistics and applied linguistics. The linguistic integration is embodied in the integrated skills: language systems (phonology, morphology, syntax, semantics, functional grammar), and receptive/productive skills (reading, listening, speaking, writing). The common tool are integrated content/task-based activities (word-building, matching/ordering, paraphrasing, summarizing, comparing, interpreting), coherently structured to ensure integrated input, practice and performance. The synergy of language systems and skills may be illustrated by reading/listening tasks, which include a leadin task for eliciting prior knowledge and pre-teaching vocabulary, note-taking while reading/listening, post-reading/listening focus on linguistic features and skills, followed by contextualized practice and a culminating (oral/written) performance activity. The applied linguistics integration entails pedagogical, methodological, psychological, strategic and affective considerations as vital

12 For theoretical framework of intra/multi/inter/transdisciplinary integration in ELP, see: Ignjatović 2020:188-192 
elements in devising practical and enjoyable learning experiences. It includes pedagogical approaches (methods, techniques, strategies), learning goals/ outcomes, classroom management (conduct/communication rules, grouping, instructions), organization tools (guidelines, mind maps, tables, charts), needs analysis and summative/formative assessment tools (questionnaires; tests, quizzes, rubrics, checklists), and learner/learning support (strategies, autonomy). For example, learner support includes: grammar and language reference charts, audio-scripts, key to exercises, progress tests, websites for practice/research, etc. ${ }^{13}$ This approach has been consistently applied in all ELP/LE courses.

In terms of $\mathbf{l a w}$, intradisciplinary integration involves law-related content knowledge, competences, values and practices from different areas of law. In particular, the first-year ELP course (B1/B1+) ${ }^{14}$ provides an introduction into the basic legal terminology, concepts, principles, legal culture, practice and values, which serve as a foundation for exploring issues related to legal education, professional ethics, legal systems, courts, judicial practice, constitution, human rights, government and elections. The materials are compiled from authentic sources (law textbooks, casebooks, legal documents, institutional websites, newspaper articles, videos, popular culture: movies, songs, cartoons), selected (for relevance), abridged (into manageable chunks), and adapted to the learners' proficiency level. The integrated law-and-language activities focus on legal terminology, contextualized practice, and culminating production activities. The exposure to law-and-language contents is imbued with professional competences (client interview, persuasive argumentation, public speaking), legal ethics (in advocacy, judiciary), discourse/genre analysis (provisions, cases, judgments), and comparative (Anglo-Saxon/American and Serbian/European-Continental) legal culture. Area-specific topics (constitutional law) are clustered into correlated units (government, elections, human rights) and explored in individual class hours. Learner support includes content-related videos, games, and resources for further research/practice. ${ }^{15}$

Building upon these core insights, the third-year elective LE 1 course (B1+/B2) ${ }^{16}$ addresses the subject-specific areas of criminal law and civil law (torts, family and succession). The authentic source included court databases, casebooks,

13 See: Ignjatović (2009). LE Files 1 (Appendices: 154-211); Ignjatović (2011). LE Files 2 (Appendices: 159-213).

14 See: Pravni fakultet Nis (2020a): ELP Course Syllabus (I year), Law Faculty Niš website (accessed 28.2.2020).

15 For example, see the list of iCivic educational games, available at https://www.icivics. org/games (28.2.2020).

16 See: Pravni fakultet Nis (2020b): LE1 Course Syllabus (III year), Law Faculty Niš (accessed 28.2.2020). 
documents, videos, popular culture, etc. The exposure to legal terminology is contextualized in genre analysis (law reports, case law, judgments) and discourse analysis (opening statements, closing arguments), exploring legal theories (punishment), documents (indictment, complaint), provisions (homicide), institutes (plea bargaining), standards (liability), procedures (appeal), and comparative legal culture (advocacy). The integrated activities focus on professional competences, performance and practices (legal research, case analysis, reasoning, argumentation, advocacy, case presentation, mock trial). For example, after examining tort-related concepts, learners explore legal provisions, analyze a case, discuss liability and legal remedies, or watch a court video, examine proceedings and language of advocacy, prepare structured oral arguments, and participate in a mock trial in class.

The fourth-year LE 2 course (B2+/C1) ${ }^{17}$ further advances the learners' discursive knowledge, competences and values in complex areas of civil law (property, intellectual property, contracts), labour/employment law, business law (company, commercial, trade law), and international (public/private) law. The integration of authentic contents is ensured through contextualized exposure to legal terminology, discourse/genre analysis (law reports, documents, contracts, transactional letters, judgments), competences (legal research, case analysis, reasoning, persuasive argumentation) and practices (problem-solving, decision-making, negotiation, project management). For example, after exploring contract terminology, learners read sample contracts, focus on contract language (legal "shall", "here/there" compounds, "negative inversion"), discuss remedies and discuss outcomes (litigation vs. alternative dispute resolution). In the follow-up, they research "smart" contracts and share findings in class, or perform criteria-based case analysis, prepare oral arguments for moot court, and decision-making processes (judgment).

\subsection{Multidisciplinary integration}

Multidisciplinary integration rests on a careful selection of contents/competences/values cutting across multiple disciplines: law and language, ethics, society, government, politics, economics, business, culture, environment, medicine, technology, etc. The ELP/LE course syllabi are thus imbued with contents and practices from correlated disciplines that may be encountered in discourse community contexts. The integration tool are content/topic/task-based and problem-project-based activities: a) discourse/genre analysis (reports, documents,

All ELP/LE syllabi include learning goals, outcomes, exam material, assessment and grading criteria.

17 See: Pravni fakultet Nis (2020c): LE2 Course Syllabus (IV year), Law Faculty Niš (accessed 28.2.2020). 
graphs, cases) involving insights from other disciplines (economics, science, technology, language); b) debates on controversial local/regional/global issues (human rights, surrogacy, migration) addressed from diverse perspectives (historical, social, cultural, ethical, environmental, medical, political, etc.); c) local community problem-solving scenarios involving multiple stakeholders' perspectives (citizens, NGOs, public/local authorities, interest groups); d) group projects on local/global issues (violence, juvenile delinquency) requiring insights from natural, social and technical sciences; e) use of digital technology for research, analysis, presentation; etc. This form of integration has a huge potential in designing cross-disciplinary learning solutions.

\subsection{Interdisciplinary integration}

Based on disciplinary and multidisciplinary tenets, interdisciplinary integration takes the instructional design to the next level. It entails multidimensional alignment and integration of contents/competences/values, pedagogy/methodology, and intra/multi/inter/transdisciplinary dimensions into a holistic learning experience within each and across the three ELP/LE courses. Huge consideration is given to authentic learning (contents, contexts, competences, practices, outcomes, assessment) and ongoing use of technology. The ultimate goal is to strike the right balance between the integrated communication competences, global competences and generic transferable skills by facilitating exploration, practice, productive performance, evaluation and reflection on learning. It is achieved by designing integrated learning material and activities that systematically, progressively, concurrently and conjointly address several goals and outcomes.

Interdisciplinary integration is embodied in contextualized learning activities: a) integrated law-and-language tasks (terminology, collocations, wordbuilding, functional grammar); b) genre/discourse analysis (legal documents, cases, judgments, contracts, transactional letters); c) discussion panels, public presentation, persuasive argumentation; d) legal research, analysis, reasoning, assessment; e) comparative approach to legal systems, culture, institutes, provisions; e) collaborative community-related projects (legislative proposals); f) simulation of discursive processes (problem-solving, decision-making, elections, mock trials, moot courts, project management, business meetings, alternative dispute resolution). In designing integrated law-and-language material/activities, special attention is given to integrated pedagogy and methodology (experiential, authentic, holistic learning; multiple intelligences); classroom management (organization, interactions, delivery); learner/learning skill/strategies (data/ media/digital literacy; assessment, exam practice; learner autonomy, life-long learning); communicative and global competences (personal/professional integrity; social/cultural literacy; interpersonal/intercultural, discursive/strategic 
skills), and transferable skills (critical thinking, constructive problem-solving; self-direction, initiative, responsibility, productivity, flexibility). These assets have been integrated within each and across the three ELP/LE courses provided at the Law Faculty in Niš.

The correlation between different areas of law (e.g. criminal, property, international law) and the application of integrated communicative, global and transferable competences in authentic contexts may be best illustrated by referring to the culminating performance activities in the three ELP/LE courses. For example, the highlights of the first-year ELP course include content/process/problem/productbased activities: debates on local/global issues, case analysis, problem-solving, persuasive argumentation, paragraph writing, and individual public speaking projects (presentation on a law-related topic of students' choice). In the third-year $L E 1$ course, the culminating activities are process/product/problem/project-based activities: discourse/genre analysis (cases, reports, judgments, indictment, complaint), case presentations (a criminal/civil case of learner's choice) and simulated mock trials (featuring legal research, analysis, reasoning, persuasive arguments, decision-making). In the fourth-year LE2 course, the culminating process/product-based and problem/project-based activities are: simulation of ADR processes (negotiation, mediation), a case presentation (a civil/labour/ business/international law case of learner's choice), and a moot court (persuasive argumentation in appellate/international courts). These multifaceted tasks are aimed at: promoting communication, critical thinking, collaboration and creativity, demonstrating learners' effective performance in authentic contexts, and fostering learner autonomy and development of generic transferable skills.

Authentic assessment of learner performance includes various summative and formative assessment instruments (tests, quizzes, rubrics, teacher/peer evaluation, feedback). For example, summative assessment (tests) cover law-and-language contents (terminology, structures, reading, summary/paragraph writing). Preparation for performance is supported by self-assessment tools: reference charts, checklists, rubrics, quizzes, games, sample videos and reference websites. Case presentations are both peer and teacher-assessed (on genre-specific assessment criteria), and followed by group feedback on essential learning. Besides the initial needs survey, learners are urged to provide ongoing feedback on the course contents, materials, methods; at the end, they may evaluate the course contents, classes, tests and teacher performance.

\subsection{Transdisciplinary integration}

Considering that transdisciplinarity is perceived as "the unity of knowledge", encompassing a body of theoretical, methodological, technical, professional, 
practical and ethical knowledge, competences, values and practices (Hirsch Hadorn, 2009:1-2) applicable in resolving "complex, multidimensional, interdependent, non-linear problems" (Klein, 2009:47), transdisciplinary integration aims to develop transdisciplinary mindsets and competences. It inevitably includes: a) the global competence (cognitive, social, discursive and affective capacity to examine local/global issues, correlate perspectives, communicate in intercultural contexts, and take constructive action), and b) transferable life/ career skills (data/media/digital literacy; social/cultural literacy; professional/ ethical and interpersonal/strategic skills; life-long learning).

In ELP/LE courses, the integration of transdisciplinary competences may be illustrated by performance activities which involve an array of integrated transdisciplinary tenets: 1 ) research on the assigned/student-selected issue, freedom of choosing sources/methods; 2) teamwork in collaborative projects (project organization, data/time management, interpersonal skills, conflict resolution); 3) developing digital competences (use of technology in research, presentations); 4) problem-solving and decision-making (in simulated jury/judicial panels, community meetings); 5) drafting legal solutions (considering local/ global circumstances); 6) presenting arguments in mock trials, moot courts, negotiation/mediation processes; 7) self-assessment and peer evaluation of presentations, relevance and implications of proposed solutions; 8) transactional writing (email, CV, legal correspondence, conference abstract); 9) micro-project management (law firm company profile, business plan, business meetings, describing products/performance), etc.

Given that LE courses commonly include a smaller number of similar-ability learners, they offer more opportunity for a negotiated syllabus design, where students participate in shaping the program by suggesting contents and contributing materials. There is also more latitude for differentiated learning, focusing on personal interests and production of student-generated material, which contributes to developing inter/transdisciplinary mindset and competences. The practical relevance of integrated (intra/multi/inter/transdisciplinary) lawand-language instruction may be also illustrated by referring to the LF students' successful participation in a number of regional and international moot court competitions since $2011 .^{18}$

18 LF student teams have participated in moot court competitions (in English) in human rights, media law, humanitarian law, international trade arbitration, international criminal law. See: Pravni fakultet u Nišu (2020d). 


\section{Concluding remarks: Challenges and Benefits of the ICL approach}

Relying on the presented structural framework and application of the ICL approach we may consider the challenges and benefits of its implementing in ELP/LE courses at the LF Niš.

The process of designing an authentic, rigorous, methodologically sound, practical and enjoyable ESP/ELP instruction is a highly complex and challenging task. First, the elaborate structure and multiple functions of the ICL approach require multidimensional integration of cognitive, pedagogical, methodological, psychological, developmental and affective aspects within each course, pluri-dimensional integration across the three courses, and hyper-dimensional integration of intra/multi/inter/transdisciplinary perspectives. It calls for constant alertness, interdisciplinary research, reconsideration, realignment, reconstruction, reevaluation, and commitment to fluid and transformative pedagogy including various integrated, negotiated and differentiated learning solutions. Second, the past practice has shown that the major challenge of ELP/ LE design has been to ensure a sound balance of the requisite communicative competence, discursive competences, global competence, and transferable skills. To that effect, additional considerations include relevant pedagogical and methodological support, gradual learner training to overcome the challenges and embrace the benefits of this approach. Third, as contemporary legal education aims to equip learners with requisite professional competences and global legal skills, it is vital to change the traditional paradigm and provide a sustainable integrated learning for discourse community purposes. Given that Legal English has been globally recognized as one of the key assets of legal education, it is vital to ensure an authentic and holistic learning experience, which will be a valuable asset in different real-world discourse community contexts.

The application of the dynamic ICL approach in the ELP/LE courses demonstrates multiple benefits. First, the ICL is an eclectic, flexible and adaptable approach which provides viable solutions for authentic, holistic and humanistic integrated learning in different learning contexts. It is based on the multidimensional integration of intra/multi/inter/transdisciplinary perspectives (knowledge/competences/values; pedagogical, methodological, psychological, developmental, affective tenets; communicative, professional, global competences and generic transferable skills). The insight into the ELP/LE integrated curriculum shows that these diverse approaches and perspectives are intrinsically correlated and complimentary; they have many common or compatible features which facilitate the integration processes. They offer ample integration opportunities, which may be used both interchangeably or concurrently. They provide a great latitude for creativity, experimentation, modification and constructive integration, which 
often results in developing ESP-specific pedagogy and methodology. Second, the examples from ELP/LE practice show that the integration occur within each and across the three courses. The common integration tools are the integrated communicative learning activities, which concurrently and conjointly address several learning goals and outcomes. The culminating performance activities most comprehensively reflect the holistic nature of authentic integrated learning, aimed at promoting learner autonomy, developing inter/transdisciplinary mindsets, demonstrating effective performance and application of the acquired knowledge and competences in new situations, or generating viable solutions for contemporary local/global issues. Third, the ICL is a dynamic and constantly evolving approach which has proven to be highly meaningful in ELP/LE contexts. Building on prior learning, it raises awareness of multiple perspectives, options, solutions and implications, enables learners to experience authentic processes in a safe learning environment, and thus prepares them for effective performance in real-world contexts. It aims to systematically expose learners to authentic contents, gradually reinforce and expand their generic and discursive competences, activate their potentials and resources, and holistically demonstrate the acquisition of integrated competences and productive performance. The inclusion of negotiated and differentiated learning solutions offers a great latitude for developing an inter/transdisciplinary mindset, demonstrating creativity and personal/professional growth, and fostering learner autonomy and life-long learning.

On the whole, given the complexity of non-linear integration processes and everchanging learner/learning needs, this paper may offer a valuable insight into the implementation of the Integrated Communicative Learning (ICL) approach in tertiary ELP/LE instruction at the LF Niš. As there is always room for improvement, the prospective practice may rest on some important insights: 1 ) the multiple roles of enthusiastic ESP/ELP practitioners (acting as researchers, course designers, managers, facilitators, technicians, counselors, therapists); 2) the need for a genuine commitment of all stakeholders to standards/outcomesbased, competence-based and value-driven learning, aimed at promoting inter/ transdisciplinary legal education and authentic, holistic and humanistic quality learning; 3 ) the need to ensure a systematic exposure to ELP/LE instruction over a number of courses rather than perceiving it as one-time (term) event; 4) a genuine endeavour to ensure highly meaningful, rigorous, coherent and enjoyable integrated learning opportunities, as an incentive for attaining integrated competences for current and prospective needs; and 5) a constant awareness of versatile, dynamic and transformative processes, based on negotiated and differentiated learning solution, and pro-active approach to implementing change for sustainable personal/professional growth and well-being. 


\section{References}

Hirsch Hadorn, G. (2009). Unity of Knowledge in Transdisciplinary Research for Sustainability, Vol. I, in: Hirsch Hadorn, G. (ed.) Encyclopedia of Life Support Systems, EOLSS Publishers/UNESCO, Oxford, UK; (pp.1-34); https://www.eolss. net/Sample-Chapters/C04/E6-49.pdf (retrieved 2.11.2019)

Klein, J. Thompson (1999). Mapping Interdisciplinary Studies, in: The Academy in Transition, J.G.Gaff (ed.), Association of American Colleges and Universities (AAC\&U), Washington, DC; https://files.eric.ed.gov/fulltext/ED430437.pdf (accessed 20.10.2019)

Klein, J. Thompson (2008). Education (Chapter 26), In: Handbook of Transdisciplinary Research; eds. G. Hirsch Hadorn, H.Hoffmann-Riem, S.Biber-Klemm, W.Grossenbacher-Mansuy, D.Joye, Ch.Pohl, E. Zemp, U.Wiesmann, Springer; https://link.springer.com/book/10.1007/978-1-4020-6699-3 (2.11.2019)

Klein, J. Thompson. (2009). Unity of Knowledge in Transdisciplinary Research for Sustainability, Vol. I, in: Encyclopedia of Life Support Systems, ed. G. Hirsch Hadorn, EOLSS Publishers/UNESCO, Oxford; https://www.eolss.net/SampleChapters/C04/E6-49-01.pdf (retrieved 2.11.2019)

Larsen-Freeman, D.; Anderson, M. (2011). Techniques \& Principles in Language Teaching, Oxford University Press

Munro, G. S. (1991). Integrating Theory and Practice in a Competency-Based Curriculum: Academic Planning at the University of Montana School of Law, In: Montana Law Review 52 (1991), University of Montana; http://scholarship.law. umt.edu/mlr/vol52/iss2/7 (accessed 19.1.2020).

Newell, W.H. (2010). Educating for a Complex World: Integrative Learning and Interdisciplinary Studies, In: Liberal Education, Vol. 96(4), AAC\&U, Washington, DC; (accessed 19. 1. 2020); https://www.researchgate.net/publication/260675213

Richards, J. C. (2006). Communicative Language Teaching Today, Cambridge University Press, UK.

Richards, J. C., Rodgers, Th. S. (1986). Approaches and Methods in Language Teaching: A description and analysis, Cambridge University Press, Cambridge, UK.

Pinner, R. (2012). Examining Authenticity and Motivation from an International Perspective, Annual Report of JACET-SIG on ESP, 14 (pp.26-35), Japan Association of College English Teachers, ESP Special Interest Group, https://www.researchgate.net/publication/281832835, (retrieved 21.09.2020)

Wegner, J. W. (2011). The Carnegie Foundation's Educating Lawyers: Four questions for Bar Examiners, in: The Bar Examiner, June 2011 (Vol. 80, no.2), Madison, 
WI; (retrieved 20.1.2020); https://thebarexaminer.org/wp-content/uploads/ PDFs/800211_Wegner.pdf

Ignjatović, G. (2020). Integrative Learning Approach in ESP/ELP: Theoretical Framework of Intradisciplinary, Multidisciplinary, Interdisciplinary, and Transdisciplinary Integration, In: Зборник радова Правног факултета у Нишу/ Collection of Papers of the Law Faculty, University of Niš, br. 88/2020 (pp.179198), Pravni fakultet, Niš; https://aseestant.ceon.rs/index.php/zrpfn/article/ view/27891/16587 (accessed 25.12.2020)

Ignjatović, G. (2017a). Multiple Intelligences in ELP Instruction in Tertiary Education: Integrated Communicative MI-based Activities in Adult ELP/LE Classrooms, In: The Journal of Teaching English for Specific and Academic Purposes, Vol.5, No.3, 2017 (pp.567-587); (accessed 20.1.2020)

Ignjatović, G. (2009). Legal English Files 1 (Intermediate coursebook), Pravni fakultet u Nišu, Niš, 2009

Ignjatović, G. (2011). Legal English Files 2 (Upper-intermediate), Pravni fakultet u Nišu, Niš, 2011

Institutional (online) sources

CoE (2020): The Common European Framework of Reference for Languages (CEFR): Global scale- CEFR levels (2001), Council of Europe, Strasbourg; https:// www.coe.int/en/web/common-european-framework-reference-languages/table-1-cefr-3.3-common-reference-levels-global-scale (28.2.2020)

GLS (2010): Global legal Skills Conference 2010 program, (accessed 17.1.2020) https://sites.google.com/site/globallegalskillsconferencev/system/app/pages/ subPages?path=/home

GSP (2013): Great School Partnership: The Glossary of Education Reform (online): Authentic Learning (Sept. 2013); https://www.edglossary.org/authentic-learning/ (accessed 25.1.2020)

iCivic.org (2020): iCivic Games, iCivic platform, Cambridge, MA, USA, https:// www.icivics.org/games (accessed 28.2.2020).

Leicester University (2020): Learning theories: David Kolb-Experiential Learning, Doctoral College, E-Resources (Study guides), University of Leicester, UK; (accessed 25.1.2020) https://www2.le.ac.uk/departments/doctoralcollege/ training/eresources/teaching/theories/kolb

OECD (2018): The Future of Education and Skills, OECD Education 2030, Position paper, OECD, Paris https://www.oecd.org/education/2030/E2030\%20 Position\%20Paper\%20(05.04.2018).pdf; (19.2.2020) 
OECD PISA (2018): the OECD PISA Global Competence Framework: Preparing youth for an inclusive and sustainable world; https://www.oecd.org/education/ Global-competency-for-an-inclusive-world.pdf

UNESCO (2012): Shaping the Education of Tomorrow: 2012 Report on the UN Decade of Education for Sustainable Development (abridged), UN Educational, Scientific and Cultural Organization, Paris; https://sustainabledevelopment. un.org/content/documents/919unesco1.pdf; (retrieved 19.2.2020)

UNESCO-IBE (2013): International Bureau of Education: Glossary of Curriculum Terminology (1.9.2019) http://www.ibe.unesco.org/... /Publications/IBE_GlossaryCurriculumTerminology2013_eng.pdf

UNICEF (2019): Global Framework on Transferable Skills, United Nations Children's Fund, NY, 2019; https://www.unicef.org/media/64751/file/Globalframework-on-transferable-skills-2019.pdf (25.9.2020).

Pravni fakultet u Nišu (2020a): Law Faculty Niš: Nastavni plan Engleski jezik/2013/ELP Course Syllabus (I year); http://www.prafak.ni.ac.rs/files/ nast_mat/eng-1-2-sem-NASTAVNI-PLAN.pdf,(access 28.7.2020).

Pravni fakultet u Nišu (2020b): Law Faculty Niš (website): Nastavni plan Engleski jezik pravne struke 1/2013/ Legal English 1 (III year); http://www. prafak.ni.ac.rs/files/silabusi/osnovne/eng-struke-1.pdf;

Pravni fakultet u Nišu (2020c): Nastavni plan Engleski jezik pravne struke 2/2013/Legal English 2 (IV year); http://www.prafak.ni.ac.rs/files/silabusi/ osnovne/eng-jezik-struke-2.pdf ; (accessed 28.7.2020).

Pravni fakultet u Nišu (2020d): Moot-court takmičenja/Law Faculty Niš: Moot court competitions; http://www.prafak.ni.ac.rs/studenti/moot-court-takmicenje.html (accessed 25.9.2020) 


\section{Gordana Ignjatović,}

Predavač engleskog jezika struke,

Pravni fakultet, Univerzitet u Nišu

\section{INTEGRISAN KOMUNIKATIVNI PRISTUP UČENJU ENGLESKOG JEZIKA PRAVNE STRUKE (ELP/LE): Praktična primena u kontekstu intra/multi/inter/transdisciplinarnih integrativnih procesa}

\section{Sažetak}

Ovaj rad predstavlja analizu Integrisanog komunikativnog pristupa učenju engleskog jezika pravne struke (ELP), tj. pravnog engleskog jezika (LE) za akademske i profesionalne potrebe, u okviru nastavnog plana i programa Pravnog fakulteta u Nišu. Prvi deo rada predstavlja konceptualno-teorijski, pedagoško-metodološki i strukturalni okvir ovog pristupa u učenju engleskog jezika struke (ESP) koji nudi održiva rešenja za kreiranje integrisanih programa. U drugom delu rada se prikazuje struktura ponuđenih (ELP/LE) kurseva, daje kratka analiza nastavnog konteksta, i obrazlaže izbor ovog pristupa učenju. Treći deo rada nudi prikaz multidimenzionalnih integrativnih procesa u okviru (ELP/LE) kurseva, sa osvrtom na intradistciplinarne, multidisciplinarene, interdisciplinarne i transdisciplinarne aspekte integracije. Analiza složene strukture, brojnih funkcija i primene ovog pristupa potkrepljena je primerima iz prakse. U finalnom delu rada, autor razmatra ključne izazove u primeni ovog pristupa, kao i brojne prednosti koje omogućavaju kreiranje komunikativne nastave zasnovane na principima initegrisanog kurikuluma, globalnih kompetencija, transferabilnih veština, i autentičnog holističkog pristupa učenju. Dugogodišnja iskustava u razvoju i primeni integrisanog pristupa mogu biti od koristi ne samo u pogledu unapredjenja nastave pravnog engleskog jezika (koji je globalno prepoznat kao jedna od važnih pravničkih veština) već $i$ cilju obezbeđivanja kvalitetnog, interdisciplinarnog i holističkog pravničkog obrazovanja.

Ključne reči: Engleski jezik pravne struke (ELP/LE), integrisani komunikativni pristup učenju, autentični holistički pristup, globalne kompetencije, transferabilne veštine. 